\title{
Persepsi mahasiswa Fakultas Ilmu Keolahragaan Universitas Negeri Yogyakarta terhadap atribut produk minuman kesehatan
}

\author{
Chairina Vidya, Fatma Zuhrotun Nisa, Ika Ratna Palupi * \\ Departemen Gizi Kesehatan, Fakultas Kedokteran Kesehatan Masyarakat dan Keperawatan, \\ Universitas Gadjah Mada. Jalan Farmako Sekip Utara, Yogyakarta 55281, Indonesia \\ * Corresponding Author. Email: iratnap@ gmail.com
}

Received: 12 June 2018; Revised: 4 November 2018; Accepted: 27 November 2018

\begin{abstract}
Abstrak
Pemberian cairan sangat penting bagi atlet untuk menghindari dehidrasi yang dapat menyebabkan gangguan fisiologis tubuh. Produk minuman kesehatan diyakini mampu meningkatkan energi dan menjaga produktivitas pada saat dan setelah melakukan aktivitas fisik seperti bekerja dan olahraga, terutama bagi para olahragawan. Perilaku membeli produk minuman kesehatan dilakukan berdasarkan preferensi dan kebutuhan konsumen, salah satunya mempertimbangkan atribut produk. Penelitian ini bertujuan untuk mengetahui persepsi mahasiswa Fakultas Ilmu Keolahragaan Universitas Negeri Yogyakarta (FIK UNY) terhadap atribut produk minuman kesehatan (harga, kemasan, merek, label, dan rasa). Penelitian menggunakan desain observasional cross sectional dengan subjek penelitian 100 orang mahasiswa FIK UNY yang diambil secara purposif. Analisis data menggunakan statistik deskriptif. Hasil penelitian menunjukkan bahwa sebagian besar subjek memiliki persepsi positif terhadap atribut produk minuman kesehatan. Kemasan yang mudah dibawa dan dipegang serta informasi nilai gizi merupakan indikator yang dianggap paling penting oleh subjek.
\end{abstract}

Kata Kunci: persepsi, atribut produk, minuman kesehatan, mahasiswa

\section{Perception on healthy drink product attributes among Sports Sciences College Students in Universitas Negeri Yogyakarta}

\begin{abstract}
Intake of fluids is very important for athletes to avoid dehydration which can cause physiological disorders of the body. Health drink products are supposed to increase energy and maintain productivity during and after physical activities such as work and exercise, especially for athletes. The behavior of buying health drink products is based on consumer preferences and needs, one of them considering product attributes. This study aimed to determine perception of students of the Faculty of Sport Sciences Yogyakarta State University (FIK UNY) on the attributes of health drink products (price, packaging, brand, label, and taste). The research used observational cross-sectional design. Subjects were 100 students of FIK UNY selected through purposive sampling. Data analysis employed descriptive statistics. The results showed that most subjects had positive perceptions on health drink product attributes. Packaging that was easy to carry and hold as well as information of nutritional value was an indicator that was considered most important by the subjects.
\end{abstract}

Keywords: perception, product attributes, healthy drink, college students

How to Cite: Vidya, C., Nisa, F., \& Palupi, I. (2018). Persepsi mahasiswa Fakultas Ilmu Keolahragaan Universitas Negeri Yogyakarta terhadap atribut produk minuman kesehatan. Jurnal Keolahragaan, 6(2), 184-192. doi:https://doi.org/10.21831/jk.v6i2.19999

d

https://doi.org/10.21831/jk.v6i2.19999

\section{PENDAHULUAN}

Minuman adalah segala sesuatu yang dapat dikonsumsi untuk menghilangkan rasa haus. Bagi atlet, minuman sangat penting bagi kesehatan tubuh. Minum air yang cukup merupakan hal yang penting untuk mempertahankan prestasi puncak sebab cairan tubuh memiliki tugas penting berikut: (1) air dalam darah menghasilkan glukosa untuk kerja otot dan membawa keluar 
hasil metabolism sampingan; (2) air dalam air seni mengeluarkan sampah metabolism; (3) air dalam keringat menghilangkan panas seluruh kulit (Clark, 2013, pp. 163-164). Pemberian cairan dan mineral pada atlet merupakan hal terpenting dalam latihan atau pertandingan yang padat. Hal ini ditujukan untuk menghindari dehidrasi maupun kekurangan mineral yang dapat menyebabkan gangguan fisiologis tubuh. Adapun minuman yang baik bagi atlet adalah minuman hipotonik yaitu minuman yang sedikit sekali mengandung partikel padat atau garam dan tidak terlalu manis (Sudiana, 2010, p.49).

Perkembangan industri minuman di Indonesia yang telah menempuh beberapa periode menunjukkan bahwa periode kelima pada tahun 1995 ditandai dengan kemunculan minuman kesehatan seperti minuman probiotik, jelly drink, dan minuman isotonik. (Koswara, 2009, p.1). Minuman isotonik merupakan salah satu minuman populer di pasar Indonesia saat ini (Feizal \& Adianto, 2012, p.222). Pada dasarnya minuman isotonik menawarkan kesegaran bagi tubuh karena mengandung elektrolit mineral yang secara efektif dapat menggantikan cairan yang hilang selama beraktivitas. Minuman isotonik juga dikenal dengan istilah sport drink yaitu minuman yang berfungsi untuk mempertahankan cairan dan garam tubuh serta memberikan energi karbohidrat ketika melakukan aktivitas.

Perilaku pembelian seseorang dapat dikatakan sesuatu yang unik sebab preferensi dan sikap terhadap objek setiap orang berbeda. Selain itu konsumen berasal dari beberapa segmen, sehingga apa yang diinginkan dan dibutuhkan juga berbeda (Randang, 2013, p.701). Perilaku membeli produk minuman kesehatan dilakukan berdasarkan preferensi dan kebutuhan konsumen, salah satunya mempertimbangkan atribut produk. Terdapat dua dimensi atribut produk yaitu atribut intrinsik dan ekstrinsik. Atribut intrinsik adalah atribut-atribut spesifik pada suatu produk yang akan menghilang saat produk tersebut dikonsumsi dan tidak dapat diubah tanpa mengubah sifat dari produk tersebut, meliputi kandungan gizi, kelezatan, rasa, aroma, warna, tekstur dan bentuk. Sedangkan atribut ekstrinsik adalah segala aspek yang berhubungan dengan suatu produk, misalnya merek, label, harga, desain, kemasan, dan kebersihan (Fandos \& Flavian, 2006, p.649). Penelitian pada kelompok usia dewasa muda di Taiwan menunjukkan bahwa atribut produk yang mempengaruhi pembelian minuman kopi kemasan yaitu varian, merk/ promosi, dan harga atau volume (Hsu \& Hung, 2005, p.361). Selain itu, kemasan produk berpengaruh signifikan terhadap kesetiaan pada suatu merk produk (brand loyalty) termasuk di dalamnya informasi label, logo, bentuk dan ukuran tulisan merk.

Dalam penelitian ini, minuman kesehatan didefinisikan sebagai produk minuman dalam kemasan yang berbentuk cair, serbuk, atau tablet yang memiliki klaim gizi dan atau klaim kesehatan. Konsumen memiliki suatu persepsi mengenai suatu produk sebelum memilih dan mengkonsumsi produk tersebut (Assael, 1992, p.186). Persepsi terhadap atribut produk menjelaskan pendapat atau tanggapan seseorang tentang karakter produk yang meliputi harga, kemasan, merek, label dan rasa: (a) Harga produk dijelaskan melalui indikator kesesuaian harga dengan manfaat produk; (b) Kemasan produk dijelaskan melalui indikator jenis dan mutu bahan kemasan, kombinasi warna dalam desain kemasan, kemudahan dibawa atau dipegang, dan kemudahan untuk disimpan; (c) Merek produk dijelaskan melalui indikator kemudahan diingat, dikenal oleh masyarakat, dan merek yang konsumen suka; (d) Label produk dijelaskan melalui indikator informasi yang tercantum pada label (komposisi atau daftar ingredient, tanggal kadaluwarsa, dan nilai gizi).

Subjek yang digunakan dalam penelitian ini adalah mahasiswa dengan bidang studi ilmu keolahragaan yang dalam aktivitasnya memerlukan dukungan asupan cairan yang memadai. Kelompok populasi ini ditengarai pernah mengkonsumsi sport drink maupun minuman kesehatan yang ada di pasaran yang diharapkan memberikan efek positif terhadap kesehatan mereka, seperti memperbaiki dan meningkatkan performa serta mencegah dan memperbaiki kehilangan cairan dan mineral dalam tubuh setelah belajar dan beraktivitas fisik. Alasan pemilihan subjek yaitu bahwa populasi dewasa muda dan atlet perguruan tinggi adalah target utama dari kampanye pemasaran perusahaan minuman energi (Buxton \& Hagan, 2012, p.1). Penelitian di Turki pada subjek mahasiswa jurusan kedokteran, olahraga dan seni menemukan bahwa alasan mahasiswa yang pertama kali mencoba mengkonsumsi minuman berenergi adalah karena mereka penasaran dengan rasanya sedangkan alasan mahasiswa yang secara rutin mengkonsumsi minuman berenergi di antaranya untuk menambah energi, supaya bisa terjaga (begadang), dan meningkatkan performa ketika mereka berolahraga.

Dari studi literatur diketahui bahwa penelitian terdahulu lebih banyak mengkaji konsumsi 
minuman berenergi maupun aspek desain kemasan produk. Penelitian ini bertujuan untuk mengetahui persepsi terhadap atribut produk minuman kesehatan yang meliputi harga, kemasan, merek, label, dan rasa sehingga dapat diketahui faktor-faktor yang mendasari konsumsi produk tersebut pada mahasiswa ilmu keolahragaan.

\section{METODE}

Penelitian ini merupakan penelitian observasional dengan rancangan cross sectional yang dilakukan pada bulan September 2014 di Fakultas Ilmu Keolahragaan Universitas Negeri Yogyakarta. Penelitian observasional adalah penelitian dimana peneliti hanya melakukan observasi tanpa memberikan intervensi pada variabel yang diteliti sedangkan desain cross sectional dalam penelitian ini bersifat deskriptif kuantitatif. Lokasi penelitian dipilih dengan alasan tersedianya populasi target sehingga memudahkan pengambilan sampel penelitian.

Populasi dalam penelitian ini adalah mahasiswa Fakultas Ilmu Keolahragaan Universitas Negeri Yogyakarta yang berjumlah 2.368 orang. Sampel ditentukan berdasarkan kriteria inklusi, yaitu pernah membeli produk minuman kesehatan dan bersedia mengikuti penelitian dengan menandatangani informed consent. Besar sampel yaitu 100 orang yang dihitung menggunakan formula Slovin dan diperoleh melalui metode pengambilan sampel non-probability dengan teknik purposive sampling. Sampel dipilih berdasarkan pertimbangan subjektif dan praktis bahwa sampel tersebut dapat memberikan informasi yang memadai untuk menjawab pertanyaan penelitian.

Prosedur penelitian meliputi persiapan (perizinan dan validasi kuesioner) yang dilanjutkan dengan pelaksanaan pengumpulan data meliputi: (1) penjelasan mengenai tujuan dan prosedur penelitian kepada calon subjek, (2) pembagian inform consent, (3) pembagian kuesioner kepada subjek yang bersedia menjadi sampel penelitian, (4) pengumpulan kuesioner oleh peneliti. Proses pengisian kuesioner didampingi oleh peneliti untuk mengantisipasi adanya pertanyaan dari responden.

Data yang dikumpulkan meliputi data karakteristik subjek dan data persepsi terhadap atribut produk. Instrumen yang digunakan dalam penelitian ini adalah kuesioner identitas subjek dan kuesioner persepsi terhadap atribut produk. Kuesioner persepsi terhadap atribut produk disusun berdasarkan skala likert dengan pilihan skala Sangat Setuju (SS), Setuju (S), Tidak Setuju (TS), dan Sangat Tidak Setuju (STS). Pada kuesioner persepsi, atribut produk yang dinilai meliputi harga, kemasan, merek, label, dan rasa.

Guna menguji ketepatan instrumen pengumpul data, sebelum penelitian dimulai juga dilakukan uji validitas dan reliabilitas kuesioner. Uji validitas dilakukan untuk mengetahui kemampuan kuesioner dalam mengukur variabel persepsi terhadap atribut produk minuman kesehatan. Validitas kuesioner pada penelitian ini diuji melalui dua tahap. Pada tahap pertama, peneliti melakukan validitas isi kuesioner (content validity). Validitas isi dilakukan untuk mengetahui sejauh mana kuesioner tersebut mewakili semua aspek yang dianggap sebagai kerangka konsep. Validasi isi dalam penelitian ini dilakukan pada 3 orang ahli dari 3 bidang ilmu yang berbeda, yaitu dari manajemen bisnis, gizi, dan farmasi dengan hasil judgment dari ahli berupa masukan yang kemudian dijadikan rekomendasi untuk perbaikan isi dalam kuesioner tersebut. Tahap kedua yaitu melakukan uji coba kuesioner kepada kelompok yang mempunyai karakteristik sama seperti subjek penelitian. Uji coba kuesioner dilakukan kepada 30 orang mahasiswa Universitas Gadjah Mada Yogyakarta yang merupakan anggota Unit Kegiatan Mahasiswa (UKM) olahraga. Setelah dianalisis dengan metode Corrected Item Total Correlation, yaitu mengkorelasikan skor item pertanyaan dengan skor total pertanyaan dan mengkorelasikannya terhadap nilai koefisien tersebut, diperoleh 13 butir pertanyaan valid $(r>0,361)$ dari jumlah awal 23 butir pertanyaan dalam kuesioner. Selain itu, uji reliabilitas dengan metode Alpha-Cronbach memperoleh nilai alpha sebesar 0,854 $(>0,70)$ sehingga kuesioner dinyatakan reliabel dan layak untuk digunakan sebagai instrumen penelitian.

Analisis data penelitian dilakukan dengan langkah-langkah berikut: (1) melakukan editing untuk mengecek kelengkapan, relevansi, dan konsistensi data yang terkumpul; (2) melakukan koding atau membuat kode-kode untuk mempermudah proses entri data; (3) melakukan analisis univariat menggunakan statistik deskriptif untuk mengetahui gambaran umum karakteristik responden dan gambaran persepsi terhadap atribut produk yang meliputi harga, kemasan, merek, label, dan rasa dengan bantuan software SPSS versi 20. Pada penelitian ini analisis Top Two Boxes Bottom Two Boxes digunakan untuk mengetahui persepsi subjek terhadap produk minuman kesehatan dilihat dari jawaban teratas, 
yaitu subjek yang menjawab sangat setuju (SS) dan setuju (S) untuk setiap indikator. Hasil analisis kemudian diurutkan dari indikator dengan nilai tertinggi hingga terendah.

\section{HASIL DAN PEMBAHASAN}

\section{Karakteristik Subjek}

Subjek penelitian ini adalah 100 orang mahasiswa FIK UNY Program Studi Pendidikan Jasmani Kesehatan dan Rekreasi (PJKR) dan Pendidikan Kepelatihan Olahraga (PKO) angkatan 2009 hingga 2014 yang berasal dari beberapa cabang olahraga (Tabel 1).

Tabel 1. Karakteristik subjek

\begin{tabular}{|c|c|c|c|}
\hline No. & Karakteristik & $\mathrm{n}$ & $\%$ \\
\hline \multirow[t]{3}{*}{1.} & Jenis Kelamin & & \\
\hline & Laki-laki & 95 & 95 \\
\hline & Perempuan & 5 & 5 \\
\hline \multirow[t]{3}{*}{2.} & Usia & & \\
\hline & 17-19 tahun & 66 & 66 \\
\hline & 20-23 tahun & 34 & 34 \\
\hline \multirow[t]{3}{*}{3.} & Program Studi & & \\
\hline & PJKR & 8 & 8 \\
\hline & PKO & 92 & 92 \\
\hline \multirow[t]{6}{*}{4.} & Cabang Olahraga & & \\
\hline & Sepakbola & 61 & 61 \\
\hline & Voli & 14 & 14 \\
\hline & Bulutangkis & 10 & 10 \\
\hline & Basket & 5 & 5 \\
\hline & Lainnya & 10 & 10 \\
\hline \multirow[t]{5}{*}{5.} & $\begin{array}{l}\text { Minuman kesehatan yang sering } \\
\text { dibeli }^{1}\end{array}$ & & \\
\hline & Minuman isotonik & 56 & 56 \\
\hline & Susu fermentasi & 18 & 18 \\
\hline & $\begin{array}{l}\text { Minuman isotonik mengandung } \\
\text { vitamin } C\end{array}$ & 18 & 18 \\
\hline & Lainnya & 8 & 8 \\
\hline
\end{tabular}

Keterangan: ${ }^{1}$ kemasan berupa botol plastik maupun kaca, penyajian data tanpa menyebutkan merk dagang

Tabel 1 menunjukkan 66\% subjek berusia remaja (17-19 tahun). Menurut Kotler \& Amstrong (1997), selera seseorang terhadap barang dan jasa serta kecepatan seseorang dalam menerima informasi dapat dipengaruhi oleh faktor usia. Seseorang dengan usia muda relatif lebih cepat menerima sesuatu yang baru sehingga kelompok masyarakat berusia muda sering kali menjadi target pemasaran produk oleh produsen. Di samping itu, produk minuman kesehatan yang paling banyak dibeli subjek adalah minuman isotonik (56\%). Produk tersebut diketahui mengandung mineral elektrolit, tanpa pengawet dan pemanis buatan sehingga diklaim aman dikonsumsi. Minuman isotonik memiliki peluang yang besar untuk dikonsumsi oleh banyak orang. Oleh karena proses pembuatannya yang mengacu pada ilmu pengetahuan, produk ini aman untuk dikonsumsi dan dapat memenuhi kebutuhan tubuh terutama cairan, energi dan elektrolit.

\section{Persepsi terhadap Atribut Harga}

Persepsi terhadap atribut harga dijelaskan melalui indikator kesesuaian harga dengan manfaat produk (Gambar 1).

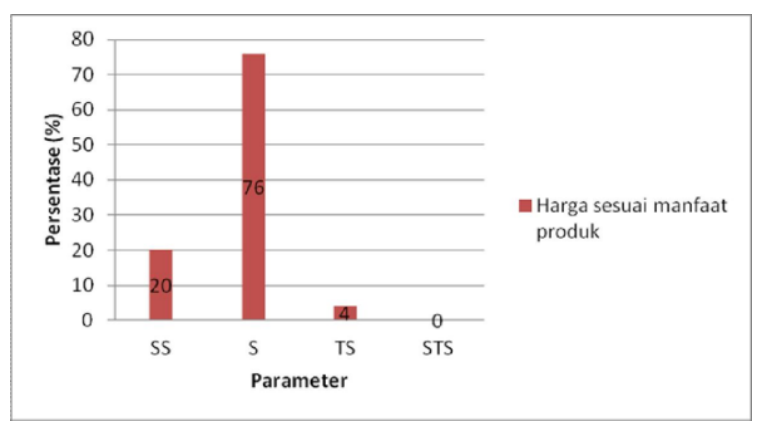

Gambar 1. Persepsi terhadap Atribut Harga

Gambar 1 menunjukkan sebagian besar (95\%) subjek sangat setuju dan setuju bahwa harga produk minuman kesehatan sesuai dengan manfaat produk. Menurut teori perilaku konsumen (Sumarwan, 2004), harga adalah atribut produk atau jasa yang paling sering digunakan oleh konsumen untuk mengevaluasi produk.

Produk-produk pangan dengan klaim kesehatan biasanya menawarkan harga yang relatif lebih tinggi dibandingkan produk pangan lainnya. Namun produk-produk-produk tersebut juga menawarkan berbagai manfaat yang menguntungkan bagi konsumen. Harga yang tinggi biasanya menunjukkan kualitas produk yang lebih baik dan menawarkan manfaat yang lebih tinggi dibandingkan produk lain yang relatif lebih murah (Kotler \& Amstrong, 1997).

Produk minuman kesehatan seperti produk minuman isotonik memiliki harga yang relatif lebih tinggi dibandingkan produk-produk minuman kemasan lainnya, namun menawarkan manfaat yang menguntungkan bagi konsumen. Oleh karena itu, subjek bersedia mengeluarkan sejumlah uang untuk memperoleh manfaat produk tersebut. Salah satu produk minuman isotonik ternama mengklaim bahwa selain aman bagi kesehatan, produknya mampu menggantikan cairan tubuh yang hilang dan memulihkan stamina bagi orang yang mengkonsumsinya. Pernyataan ini didukung oleh penelitian tentang efektifitas minuman suplemen dalam mengembalikan keseimbangan cairan tubuh pada dehidrasi yang menunjukkan bahwa minuman kesehatan seperti minuman isotonik mampu 
mengembalikan keseimbangan cairan tubuh pada dehidrasi ringan akibat aktivitas aerobik intensitas sedang dalam waktu 15 menit setelah exercise (Flora, 2005).

\section{Persepsi terhadap Atribut Kemasan}

Persepsi terhadap atribut kemasan dijelaskan melalui beberapa indikator, yaitu jenis dan mutu bahan kemasan, kombinasi warna dalam desain kemasan, kemudahan dibawa atau dipegang, dan kemudahan untuk disimpan (Gambar 2).

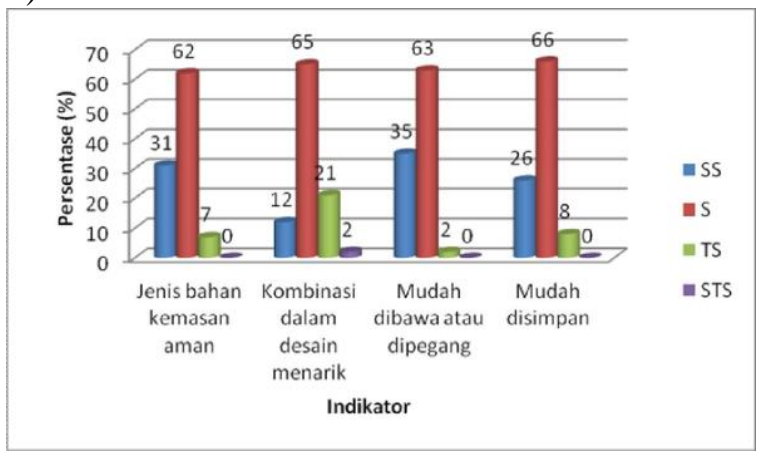

Gambar 2. Persepsi terhadap atribut kemasan

Gambar 2 menunjukkan subjek yang tidak setuju bahwa jenis bahan kemasan produk minuman kesehatan aman sebesar 7\%, kombinasi warna desain kemasan menarik $21 \%$, kemasan mudah dibawa atau dipegang $2 \%$, dan kemasan mudah disimpan $8 \%$.

Kemasan memiliki peran penting berkaitan dengan kualitas suatu produk. Selain berfungsi untuk mencegah terjadinya pembusukan dan kerusakan, melindungi produk dari kotoran, dan membebaskan pangan dari jasad renik patogen, kemasan juga dijadikan silent salesman yang dapat menjadi penentu penjualan makanan. Kemasan menjadi salah satu daya tarik suatu produk sehingga mendorong konsumen untuk mencoba produk tersebut (Limerich \& Wahyuningtias, 2013).

Hasil penelitian menunjukkan sekitar seperlima subjek menyatakan warna sebagai atribut kemasan yang masih bisa ditingkatkan dalam penampilan botol minuman kesehatan. Warna merupakan salah satu unsur terpenting dalam desain kemasan. Hal yang pertama kali diperhatikan oleh konsumen dari kejauhan adalah warna dari kemasan. Desain kemasan dengan kombinasi warna yang menarik dapat mempengaruhi konsumen dalam memilih suatu produk. Penelitian yang dilakukan di Bandung tentang persepsi terhadap desain kemasan produk minuman isotonik menunjukkan bahwa desain kemasan produk minuman isotonik yang populer di kalangan olahragawan atau atlet dijadikan sebagai contoh produk dengan desain kemasan terbaik untuk produk minuman kesehatan karena memiliki desain warna yang cerah/terang yang sesuai dengan kesan kesehatan. Dalam penelitian tersebut juga disebutkan bahwa desain kemasan minuman isotonik yang baik dan menarik adalah kemasan yang memiliki logo dan jenis huruf yang simpel, menggunakan warna yang konsisten dan terang/cerah, botol kemasan berwarna terang/ transparan sehingga keunikan bentuk botol dapat terlihat dengan jelas, menggunakan warna yang tepat serta gambar dengan ukuran dan posisi yang tepat sehingga memudahkan konsumen dalam mengidentifikasi manfaat dari produk tersebut (Feizal \& Adianto, 2012, p.222).

Peran vital dari kemasan adalah untuk melindungi produk dan konsumen. Jenis bahan kemasan yang aman menjadi salah satu aspek dalam kemasan yang dianggap penting dan diperhatikan oleh konsumen karena dapat menjaga kualitas produk. Begitu juga dengan bentuk dan ukuran kemasan yang berkaitan dengan penyimpanan dan penggunaan produk (Caudhary, 2014, p. 19). Bentuk dan ukuran kemasan berkaitan dengan masalah ergonomis seperti kemudahan saat dipegang dan disimpan.

Hasil penelitian menunjukkan sebagian besar 93\% sangat setuju dan setuju bahwa jenis bahan kemasan aman. Produk-produk minuman kesehatan mengandung zat-zat gizi tertentu yang mana jika tidak dikemas dalam kemasan yang tepat maka akan merusak kualitas produk tersebut, sehingga jenis bahan kemasan produk menjadi perhatian produsen.

Hampir seluruh (98\%) subjek juga setuju bahwa kemasan produk mudah dipegang. Pernyataan tersebut didukung oleh penelitian yang dilakukan pada konsumen minuman isotonik di Yogyakarta yang menunjukkan bahwa sebagian besar responden setuju bahwa produk minuman isotonik memiliki kemasan yang praktis untuk dibawa kemana-mana (Albari, 2007). Hal ini juga yang menjadi salah satu alasan responden memilih produk tersebut.

\section{Persepsi terhadap Atribut Merek}

Persepsi terhadap atribut merek dijelaskan melalui beberapa indikator, yaitu mudah diingat, dikenal oleh masyarakat, merek yang konsumen suka (Gambar 3). 
Jurnal Keolahragaan 6 (2), 2018 - 189

Chairina Vidya, Fatma Zuhrotun Nisa, Ika Ratna Palupi

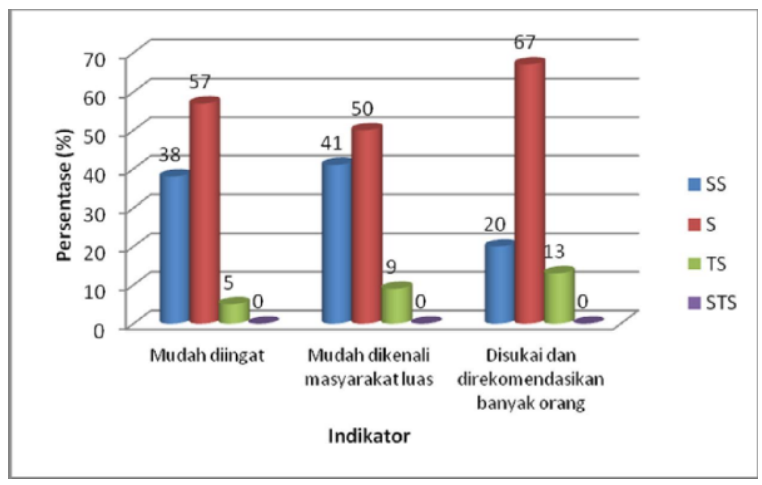

Gambar 3. Persepsi terhadap Atribut Merek

Gambar 3 menunjukkan subjek yang tidak setuju bahwa merek produk minuman kesehatan mudah diingat sebesar 5\%, mudah dikenali oleh masyarakat luas 9\%, serta disukai dan direkomendasikan oleh banyak orang $13 \%$.

Merek adalah nama penting bagi suatu produk atau jasa. Merek merupakan simbol dan indikator kualitas suatu produk. Merek suatu produk menjadi sangat penting karena berbagai faktor, salah satunya adalah merek dapat memudahkan proses pengambilan keputusan pembelian oleh konsumen (Durianto \& Sugiarto, 2001). Atribut merek menjadi salah satu atribut yang sangat menarik perhatian konsumen dan juga mempengaruhi konsumen dalam membeli susu bubuk. Merek yang telah dikenal oleh konsumen dapat mempengaruhi preferensi konsumen terhadap produk tersebut (Alvita, 2008). Merek-merek produk yang telah lama dikenal oleh konsumen dapat menjadi sebuah citra bahkan simbol status bagi produk tersebut yang mana berkaitan dengan persepsi konsumen terhadap produk (Sumarwan, 2004). Citra merek atau brand image adalah bagaimana merek dipersepsikan oleh konsumen berkenaan dengan persepsi produk (Simamora, 2002).

Hasil penelitian menunjukkan bahwa produk minuman kesehatan yang paling banyak dibeli oleh responden adalah produk dari jenis minuman isotonik. Sebagian besar responden setuju bahwa merek produk minuman isotonik yang populer di kalangan olahragawan dan atlet mudah diingat dan dikenali oleh masyarakat luas. Produk minuman isotonik merupakan produk yang paling diingat atau mudah diingat dan sangat familiar bagi responden (Gautama, Kencana, \& Suciptawati, 2012; Pratama \& Munandar, 2010). Promosi mungkin menjadi salah satu alasan suatu produk dapat sangat dikenal oleh konsumen. Program dan kegiatan komunikasi pemasaran seperti periklanan dan promosi penjualan dengan menonjolkan keung- gulan atau kekhasan produk dapat membentuk citra merek (brand image) yang kuat melekat dalam ingatan konsumen (Albari, 2007).

\section{Persepsi terhadap Atribut Label}

Persepsi terhadap atribut label dijelaskan melalui beberapa indikator, yaitu informasi komposisi atau daftar ingredient, tanggal kadaluwarsa, dan nilai gizi (Gambar 4).

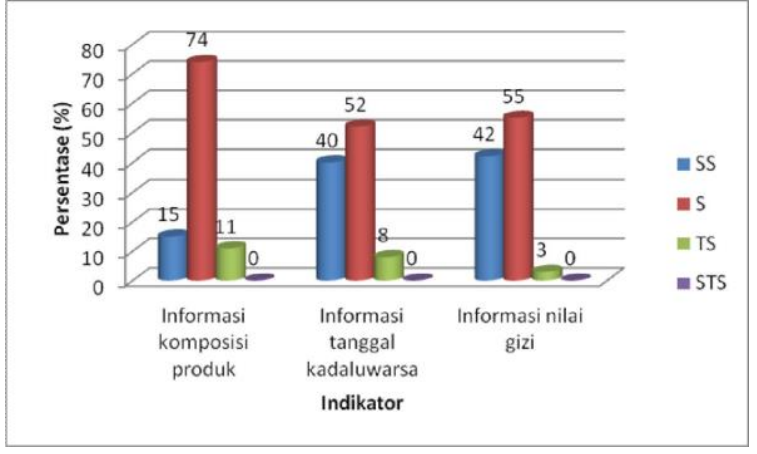

Gambar 4. Persepsi terhadap Atribut Label

Gambar 4 menunjukkan sebagian besar responden setuju bahwa adanya informasi komposisi produk yang lengkap, informasi tanggal kadaluwarsa, dan informasi nilai gizi pada label produk minuman kesehatan tidak mempengaruhi pilihan responden, masing-masing sebanyak $11 \%, 8 \%$, dan $3 \%$.

Menurut Undang-Undang No. 7 Tahun 1996, label pangan adalah setiap keterangan mengenai pangan yang berbentuk gambar, tulisan, kombinasi keduanya, atau bentuk lain yang disertakan pada pangan, dimasukkan ke dalam, ditempelkan pada, atau merupakan bagian kemasan pangan (Presiden Republik Indonesia, 1996). Produk-produk pangan dengan klaim kesehatan dan gizi seperti produk minuman kesehatan biasanya mengandung komposisi bahan atau zat-zat gizi tertentu yang dibutuhkan oleh sebagian konsumen sehingga pencantuman informasi komposisi produk dan informasi nilai gizi pada label menjadi salah satu hal yang diperhatikan karena konsumen dapat memperoleh informasi mengenai komposisi bahan dan zat gizi yang terkandung dalam produk tersebut.

Informasi tersebut akan digunakan oleh konsumen untuk mengidentifikasi apakah komposisi bahan dan zat-zat gizi yang terkandung pada produk sesuai dengan apa yang dibutuhkannya, dan dapat membantu konsumen dalam menentukan pilihan terhadap produk yang akan dibeli dan dikonsumsinya tersebut, karena jika berbicara tentang produk-produk kesehatan, konsumen biasanya ingin mengetahui secara detail mengenai apa yang akan mereka konsumsi 
(Feizal \& Adianto, 2012, p.225) terutama bagi konsumen yang peduli terhadap kebutuhan gizi dan kesehatan tubuhnya, seperti para olahragawan. Konsumen yang sangat perhatian/peduli terhadap masalah gizi dan kesehatan lebih sering menggunakan label informasi nilai gizi dalam memilih produk yang akan dikonsumsinya (Drichoutis, Lazaridis, \& Nayga Jr., 2006).

Beberapa penelitian menunjukkan bahwa berbagai macam informasi pada label seperti informasi nilai gizi dan informasi tanggal kadaluwarsa menjadi hal yang sangat diperhatikan oleh konsumen. Label pada produk susu bubuk dan susu cair disepakati sebagai salah satu atribut produk yang mampu mempengaruhi konsumen dalam membeli susu bubuk dan susu cair (Alvita, 2008). Label juga mampu menarik minat konsumen produk makanan khas karena berkaitan dengan informasi produk (Rasyid, 2009). Informasi pada produk seperti komposisi produk, informasi nilai gizi, dan informasi tanggal kadaluwarsa merupakan stimulus yang akan membentuk persepsi konsumen.

\section{Persepsi terhadap Atribut Rasa}

Persepsi terhadap atribut rasa dijelaskan melalui beberapa indikator, yaitu sesuai dengan selera, rasanya enak, dan rasa bervariasi (Gambar $5)$.

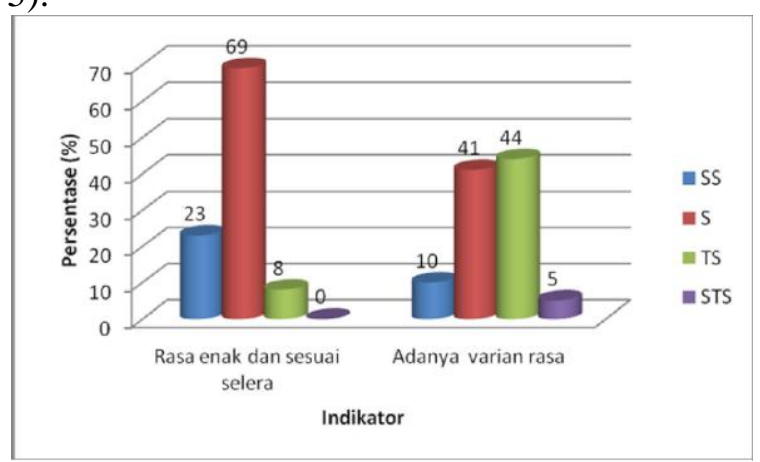

Gambar 5. Persepsi terhadap Atribut Rasa

Gambar 5 menunjukkan subjek yang tidak setuju bahwa rasa produk minuman kesehatan enak dan sesuai selera sebesar 8\%. Persepsi konsumen dapat diidentifikasi dari warna, bentuk, dan rasa produk (Kazmi, 2012). Akan tetapi, hampir seperuh (49\%) subjek tidak setuju dan sangat tidak setuju bahwa produk memiliki varian rasa. Informasi ini dapat menjadi peluang pengembangan produk bagi produsen minuman kesehatan. Adanya varian rasa atau pilihan rasa dapat membantu konsumen memilih produk dan tidak bosan dengan rasa yang monoton.

\section{Analisis Top Two Boxes Bottom Two Boxes}

Analisis Top Two Boxes Bottom Two Boxes adalah metode menggabungkan persentase jawaban responden dalam skala likert yang digunakan untuk mengetahui bagaimana perbandingan antara jumlah bottom option, yaitu skala sangat tidak setuju dan tidak setuju dengan top option, yaitu skala setuju dan sangat setuju (Thio, 2008). Pada penelitian ini analisis Top Two Boxes Bottom Two Boxes digunakan untuk mengetahui persepsi responden terhadap produk minuman kesehatan dilihat dari jawaban teratas, yaitu responden yang menjawab sangat setuju dan setuju untuk setiap indikator. Hasil analisis dapat dilihat pada Tabel 2.

Tabel 2. Analisis Top Two Boxes - Bottom Two Boxes $(T B-B T B)$

\begin{tabular}{clll}
\hline No. & \multicolumn{1}{c}{ Indikator } & $\begin{array}{c}\text { TB } \\
(\%)\end{array}$ & $\begin{array}{c}\text { BTB } \\
(\%)\end{array}$ \\
\hline 1. & $\begin{array}{l}\text { Kemasan mudah dibawa atau } \\
\text { dipegang }\end{array}$ & 28 \\
2. & Informasi nilai gizi & 97 & 3 \\
3. & Harga sesuai manfaat produk & 96 & 4 \\
4. & Merek mudah diingat & 95 & 5 \\
5. & Jenis bahan kemasan aman & 93 & 7 \\
6. & Kemasan mudah disimpan & 92 & 8 \\
7. & Rasa enak dan sesuai selera & 92 & 8 \\
8. & Informasi tanggal & 92 & 8 \\
kadaluwarsa & & \\
9. & Merek mudah dikenali oleh & 91 & 9 \\
masyarakat luas & & \\
10. & Informasi komposisi produk & 89 & 11 \\
11. & Merk disukai dan & 87 & 13 \\
& direkomendasikan banyak & & \\
orang & & 23 \\
12. & Kombinasi warna dalam & 77 & 23 \\
desain kemasan & & \\
13. & Adanya varian rasa & 51 & 49 \\
\hline
\end{tabular}

Tabel 2 menunjukkan bahwa persentase pada kolom Top Two Boxes lebih besar daripada persentase pada kolom Bottom Two Boxes sehingga dapat disimpulkan bahwa persepsi responden terhadap atribut produk cenderung baik atau positif. Adapun indikator atribut produk yang paling dominan adalah kemasan mudah dibawa atau dipegang dan informasi nilai gizi. Sebagian besar subjek setuju bahwa kemasan mudah dibawa atau dipegang dan informasi nilai gizi mempengaruhi pilihan, masing-masing sebesar $98 \%$ dan $97 \%$. Hal ini menunjukkan bahwa kedua indikator tersebut merupakan indikator yang dianggap paling penting oleh responden.

Sebagian besar subjek menganggap penting kemasan yang mudah dibawa atau dipegang. Hal ini menunjukkan bahwa kemasan produk 
yang ergonomis baik dari segi bentuk dan ukuran lebih disukai oleh konsumen karena praktis dibawa kemana-mana. Selanjutnya, sebagian besar subjek juga menganggap penting informasi nilai gizi. Penggunaan label informasi nilai gizi dapat mempengaruhi perilaku pembelian konsumen. Label informasi nilai gizi mempengaruhi perilaku pembelian konsumen karena konsumen ingin menghindari zat-zat gizi yang negatif dalam suatu produk makanan (Drichoutis, et al., 2006). Selain itu, dengan memperhatikan label informasi nilai gizi konsumen juga dapat mengontrol makanan yang dikonsumsi. Penggunaan label informasi nilai gizi secara signifikan berhubungan dengan asupan yang sehat (Graham \& Laska, 2012).

Bagi kelompok masyarakat yang sangat concern terhadap masalah kesehatan dan gizi, seperti misalnya olahragawan demi mendukung performa mereka dalam meraih prestasi, penggunaan label informasi nilai gizi tersebut tentu sangat bermanfaat untuk menjaga asupan agar tetap sehat, sehingga kelompok masyarakat ini berpeluang lebih besar untuk memperhatikan dan menggunakan label informasi nilai gizi. Mereka yang sedang menjalani diet khusus dan mereka yang perhatian terhadap masalah kesehatan lebih menyukai dan lebih sering menggunakan label informasi nilai gizi dalam memilih produk yang akan dikonsumsinya (Drichoutis, et al., 2006). Selain itu, tujuan konsumen dalam rangka kesehatan dapat meningkatkan perhatian dan penggunaan label informasi nilai gizi, khususnya untuk tujuan kesehatan yang mengarah pada diet zat gizi tertentu (Van Herpen, \& Van Trijp, 2011).

Produk-produk minuman dalam kemasan termasuk produk minuman kesehatan memiliki komposisi zat gizi tertentu didalamnya yang apabila tidak sesuai dengan apa yang dibutuhkan oleh konsumen maka akan merugikan konsumen itu sendiri, khususnya bagi konsumen yang peduli terhadap kebutuhan gizi dan kesehatan tubuhnya, seperti para olahragawan dan atlet. Atlet memiliki kebutuhan khusus terhadap asupan zat gizi tertentu (Burkhart \& Pelly, 2013) sehingga penting untuk mengetahui komposisi zat gizi yang terkandung. Oleh karena itu pula responden memilih informasi nilai gizi sebagai salah satu indikator yang dianggap paling penting.

\section{SIMPULAN}

Sebagian besar mahasiswa ilmu keolahragaan memiliki persepsi yang positif terhadap atribut produk minuman kesehatan. Indikator atribut produk yang dianggap paling penting adalah kemasan yang mudah dibawa atau dipegang dan informasi nilai gizi. Harga, merek dan bahan kemasan merupakan indikator atribut yang berturut-turut dianggap penting setelah informasi nilai gizi pada label. Disarankan bagi produsen produk minuman kesehatan untuk dapat mempertahankan atribut produk dengan kemasan yang praktis dibawa kemana-mana dan memiliki informasi yang lengkap dan jelas pada label kemasan serta mengembangkan produk yang memiliki varian rasa beragam dan warna kemasan yang menarik. Bagi peneliti selanjutnya, disarankan untuk melakukan penelitian lanjutan dengan menambahkan atribut manfaat dan frekuensi konsumsi produk minuman kesehatan sebagai variabel yang diteliti serta menggunakan metode wawancara mendalam untuk dapat menggali lebih jauh persepsi mahasiswa.

\section{DAFTAR PUSTAKA}

Albari, A. (2007) Asosiasi merek (brand association) minuman isotonik di Yogyakarta. Jurnal Fenomena, 5(1).

Alvita, R. (2008). Hubungan antara persepsi dan preferansi konsumen dalam kaitannya dengan pengambilan keputusan pembelian susu bubuk dan susu cair (Studi kasus di Perumahan Sekardangan, Kecamatan Sidoarjo, Kabupaten Sidoarjo). Skripsi, tidak dipublikasikan. Universitas Brawijaya.

Assael, H. (1992) Consumer behavior and marketing action, $4^{\text {th }} \quad$ Edition. Massachusetts: PWS-Kent Publishing Company.

Burkhart, S.J., \& Pelly, F.E. (2013). Athlete use and opinion of point of choice nutrition labels at major international competition. Appetite, 70(1), 6-13. doi: https://doi.org/10.1016/j.appet.2013.06.08 0

Buxton, C., \& Hagan, J. E. (2012). A survey of energy drinks consumption practices among student-athletes in Ghana: Lessons for developing health education intervention programmes. Journal of the international society of sports nutrition, 9(1), 1-8.

Caudhary, S. (2014). The role of packaging in consumer's perception of product quality. International Journal of Management and Social Sciences Research, 3(3), 17-21. 
Jurnal Keolahragaan 6 (2), 2018 - 192

Chairina Vidya, Fatma Zuhrotun Nisa, Ika Ratna Palupi

Clark, N. (2014) Nancy's clark sports nutrition guidebook $5^{\text {th }}$ edition. Champaign IL: Human Kinetics Chicago.

Drichoutis, A.C., Lazaridis, P. \& Nayga Jr., R.M. (2006). Consumers' use of nutritional labels: a review of research studies and issues. Academy of Marketing Science Review, 9.

Durianto, D., \& Sugiarto, TS. (2001). Strategi menaklukkan pasar. Jakarta: PT Gramedia Pustaka Utama.

Fandos, Carmina \& Flavia'n, Carlos. (2006). Intrinsic and extrinsic quality attributes, loyalty and buying intention: An analysis for a PDO product. British Food Journal, 108(8), 646-662.

Feizal, A.A.G., \& Aldianto (2012). Consumer perception toward health drinks packaging design. Journal of Business and Management, 1(4), 221- 228.

Flora, R. (2005). Efektivitas minuman suplemen dalam mengembalikan keseimbangan cairan tubuh pada dehidrasi akibat aerobik intensitas sedang. Tesis. Universitas Gadjah Mada.

Gautama, I.P.W., Kencana, I.P.E.N. \& Suciptawati, L.P. (2012). Persepsi konsumen minuman isotonik di Kota Denpasar. Jurnal Matematika, 1(1), 40-46.

Graham, D. J., \& Laska, M. N. (2012). Nutrition label use partially mediates the relationship between attitude toward healthy eating and overall dietary quality among college students. Journal of the Academy of Nutrition and Dietetics, $112(3), 414-418$.

Van Herpen, E., \& Van Trijp, H. C. (2011). Front-of-pack nutrition labels. Their effect on attention and choices when consumers have varying goals and time constraints. Appetite, 57(1), 148-160.

Hsu, J. L \& Hung, W.J. (2005). Packed coffee drink consumption and product attribute preferences of young adults in Taiwan. Food Quality and Preference, 16(4), 361-
367.

doi:

https://doi.org/10.1016/j.foodqual.2004.0 6.004

Kazmi, S.Q. (2012). Consumer perception and buying decision (Pasta study). International Journal of Advancements in Research \& Technology, 1(6), 1-10.

Koswara, S. (2009). Minuman Isotonik. Universitas Muhammadiyah Semarang. ebookpangan.com

Kotler, P \& Amstrong, G. (1997). Dasar-dasar pemasaran. Terjemahan Jilid I. Jakarta : Intermedia.

Limerich, L \& Wahyuningtias, D. (2013). Pengaruh label kemasan pangan terhadap keputusan pembelian makanan ringan (studi kasus pada siswa SMA Candra Naya). Tesis, tidak dipublikasikan. Universitas Bina Nusantara.

Pratama, F. \& Munandar, J.M. (2010) Analisis brand equity Pocari Sweat dalam persaingan industri minuman (Studi kasus Mahasiswa di Bogor). Jurnal Manajemen dan Organisasi, 1(1), 24-29.

Randang, W. (2013). Kualitas produk, atribut produk dan ekuitas merek pengaruhnya terhadap keputusan pembelian minyak goreng. Jurnal EMBA, (1(3), 701-709.

Rasyid, A. K. (2012). Atribut produk intrinsik dan ekstrinsik yang dipertimbangkan konsumen dalam membeli produk cemilan khas Kota Malang, Skripsi. Fakultas Ekonomi Universitas Brawijaya.

Simamora, B. (2002). Aura merek. Jakarta: PT Gramedia.

Sudiana, I.K. (2010) Asupan nutrisi seimbang sebagai upaya mencegah kemerosotan prestasi olahraga. Jurnal IKA, 8(1), 41-55.

Sumarwan, U. (2004). Perilaku konsumen. Bogor Selatan: Ghalia Indonesia.

Thio, S. (2008). Persepsi konsumen terhadap makanan organik di Surabaya. Jurnal Manajemen Perhotelan, 4(1), 18-27. doi: https://doi.org/10.9744/jmp.4.1.18-27 